\title{
Digitalization of Tourism: Creating Tourist Information Center
}

\author{
Mustafaeva Z.A. Tappaskhanova E.O.* Thamitlokova Yu.O.
}

\author{
Institute of Law, Economics and Finance, Kabardino-Balkarian State University, Nalchik, Russia \\ *Corresponding author. Email: tappazliza777@mail.ru
}

\begin{abstract}
The development of the digital economy changes the modern development of many economic activities, along with tourism and recreation. The article shows that in the conditions of the economy digitalization information becomes the key factor for the development of this industry. The article also shows the modern informational condition of tourism and recreation development in North Caucasus, and the KabardinoBalkarian Republic, which is part of it. We concluded, that the development of tourism and recreation in these territories goes slow. The article considers the factors, which prevent the development of the researched territories.

Considering the experience of tourist-information centers of Russia and other countries, the creation necessity of such a center in Kabardino-Balkaria, based on logistic management is justified. The goals and objectives, the results of the activity, the structure and mechanism of activity of the tourist - information center are considered. The logistic support of the center is considered.

The relevance of creating a center for providing high-level tourist information services is substantiated, which will make it possible to coordinate information flows in the tourism sector, the formation of a database of tourism industry facilities in the region.
\end{abstract}

Keywords: tourism, recreation, digital economy, tourism information infrastructure, blockchain, mobile

applications in tourism

\section{INTRODUCTION}

With the digitalization of all sectors of the economy, there is a steady trend towards simplifying the use of services. In addition to the quality of services, consumers have become increasingly interested in the simplicity of the search for services and payment methods. In these conditions, information becomes almost one of the main factors in the development of regional tourism. There is a search for various innovative methods to solve this problem $[13 ; 17]$. That explains the close attention paid by the Government of the Russian Federation to this issue $[6 ; 9 ; 10]$.

An innovative way in the tourism development is the creation of a tourist information center (TIC). The work reveals the development information level of the tourism sectors in Russia and North Caucasus Federal District (NCFD). Examples of positive experience of using TIC in foreign countries are given. Based on the well-known scientific research and practice of the successful use of the TIC, the most important conclusion is a direct link between the level of information support of the tourism sector and the level of its development.

During the researches, the causes of the present development problems of the tourism and recreation sector of the North Caucasus Federal District and regions were identified. The digitalization of this necessity this most important economic area, in particular, the creation of the TIC is substantiated.

The work defines the goals and objectives of creating a TIC, the results from the use of logistic management in the center, the structure of the TIC, the logistics of the center. It considers what place tourist navigation and tourist maps and maps occupy in providing tourist information. Along with the mechanism of functioning of the TIC and what are the expected results from its activities.

Studying the nature, formation and development direction of the TIC made it possible to conclude that the TIC is a promotion tool for the North-Caucasian Federal District and the regions that are part of it. Today there is no similar product in the regional tourism markets.

The development and implementation of the TIC in the Kabardino-Balkarian Republic (KBR) will help to create a positive image of the region in the eyes of potential tourists, increase the tourist flow and budget revenues of the region and give a significant impetus to its socioeconomic development. Hence, the need for the development of a TIC for the North Caucasus and other regions of the North Caucasus Federal District is obvious.

\section{RESEARCH METHODOLOGY}

During the research process, we used aspect, systemic and conceptual approaches. The aspect approach allowed us to 
choose one side of the problem based on relevance. For example, the problem of the digitalization of tourism has various aspects of one solution. For this research, we took the aspect of TIC creation. A systematic approach to the research of an object as a system in which internal and external factors that influence the results of the functioning of the object are distinguished. Using a systematic approach also allowed to determine the goals of each of its elements, based on the general purpose of the object. The conceptual approach made it possible to develop a research concept, a set of key provisions to determine the overall focus of the research. An important role in the methodology is played by research tools and methods. In the research, the following methods were used: formal logistic, general scientific and specific.

\section{RESEARCH PART}

In November 2019 on the Interparliamentary Assembly of the CIS Member States a model law about the description of TIC passed: "Tourist information and guest centers are non-profit and public-private organizations whose goals are:

assistance to public authorities in the formation and use of information resources on tourism;

- providing free of charge (to citizens and other interested parties) competent documented tourist information" [4].

A significant event in the development of tourism for Russia was 2013 when the National Association of Tourist Information Organizations (NAITO) was created - an organization created based on a non-profit partnership that united TIC of many regions, 13 TIC of Russia became the founders of the partnership. The creation of NAITO was aimed at solving the problem of developing common standards for promoting the regions, working together to promote the tourism product of the territories and, of course, exchanging the experience of TIC working in Russia.

In Russia, the created TIC registry included more than 100 institutions located in various Federal districts, ranging from the Kaliningrad region and ending with the Far East. The need to create a TIC in Russia in all regions where there are opportunities for the development of tourism has become the most important instruction from the President of the Russian Federation as a result of a meeting of the Council on Culture and Art in 2012. "To develop an allRussian system of navigation and orientation information for tourists, providing for the creation of a national tourist Internet portal, as well as the creation of tourist information centers in the Russian Federation" [7].

It was with the support of NP NAITO that a project was developed, which is a travel information exchange system and consists of 2 - information parts, which contain a single database of tourism market opportunities and a service platform that lists travel services.

The development of TIC in Russia can be said to be spontaneous and unsystematic. In our opinion, this is because in our country the formation of TIC began not so long ago in comparison with foreign countries. Therefore, the efficiency of the use of tourism resources, their promotion, both in the domestic market and in external tourism markets is not high enough.

In Russia, many regions already have their TICs in the field of tourism and recreation, which function effectively (Table 1).

Table 1 Tourist Information Centers in Russia

\begin{tabular}{|l|c|}
\hline $\begin{array}{l}\text { Title } \\
\text { Federal District }\end{array}$ & $\begin{array}{l}\text { The number of tourist } \\
\text { information centers in the } \\
\text { district }\end{array}$ \\
\hline CFD & 68 \\
\hline PFD & 23 \\
\hline SFD & 25 \\
\hline YFD & 23 \\
\hline CZFD & 51 \\
\hline UFD & 11 \\
\hline DFD & 13 \\
\hline SKFD & 2 \\
\hline Total & 216 \\
\hline
\end{tabular}

As can be seen from the data in table 1 , in the North Caucasus Federal District, the TICs are the least functioning in comparison with other federal districts, where are two in total.

It should be noted that in the North Caucasus Federal District as a whole there are all conditions for tourism and recreation to develop. The priority direction of tourism development in the North-Caucasian Federal District is health-improving and ski tourism, based on which cultural, educational, business, environmental, sports, ethnic and other types of tourism are developed.

However, the tourist and recreation complex of the North Caucasus Federal District, it does not have a high-quality tourist infrastructure and is characterized by an insufficiently high level of service, is developing at a slow pace today. This should also include such a factor as the low efficiency of positioning a tourist product on the market of the corresponding target segments [12].

Those problems in the development of tourism that take place in the North Caucasus Federal District are also characteristic of its regions, although there are specific regional problems. The study of the market of tourist services in the regions showed that they lack specialized organizations that can provide a full range of services such as information, sociological, marketing and others that would attract more tourists to the region and effectively develop inbound and domestic tourism.

The paper substantiates the need to use logistics management, which will increase the efficiency of the TIC functioning, as well as raise the quality of service in the tourism sector to a higher level, monitor and control the flow of tourists, both in the internal and in the external environment.

In foreign countries, there is extensive experience in the formation and development of similar structures of TIC. An example is a solution to this problem in France, where information support and promotion of national tourism 
products is carried out at a high level. The beginning of the creation of a tourist office in this country dates back to the distant $90 \mathrm{~s}$ of the 18th century. These circumstances explain the fact that the French tourist product has occupied a significant share in the international tourism market and entered the top three countries - leaders in this field.

In the popular European and American tourist cities in the modern period, there are numerous TICs. This situation is considered the norm, especially for those territories that set the task of becoming the most attractive place for tourists, for which the level of equipment of the TIC and their quantity is of great importance. After all, these indicators characterize the prestige of the tourist territory.

Such centers are also very popular in countries such as Switzerland, Italy, Spain, where there is an extensive network of TIC offices. The same centers are available in Tallinn, Estonia, Vienna, Austria, Latvia, Azerbaijan, etc. [2]

The experience of countries where there are a large number of TICs indicates that its modern form is an indicator of business success. It is part of the state management system in the field of tourism. TIC is an effective tool for promoting tourism services in any region where there are conditions for the development of tourism and are part of the national TIC system, which allows it to perform state functions in the tourism sector.

The development of the TIC makes it possible to effectively interact with such components as accommodation and meals, local transport, retail facilities, entertainment venues, and the production of souvenirs. Therefore, the development of the TIC should be among the priority measures for the development of tourism in the tourist and recreational areas.

One of the functions of the TIC is reference activities. This is noted by all tourists who have visited those countries where tourist infrastructure is developed. However, this is not the only function of the TIC, but only a small part of its activities.

In the Strategy of socio-economic development of the North Caucasus Federal District until 2025, it is indicated that tourism development can be achieved only through the formation of highly efficient tourism services based on the functioning of small companies. The lack of a unified concept of a territorial system of information centers in the field of tourism and recreation often impedes the formation and development of this most important industry. Hence, the creation of the TIC becomes a key factor in the development of tourism in the tourist territories of the North Caucasus Federal District.

It should be noted that for the KBR, which is part of the North Caucasus Federal District, the success of tourism and recreation is an essential condition for its socioeconomic status. However, today, unfortunately, the potential in the field of tourism and recreation, which is available in the republic, is not used properly $[15 ; 16]$. Hence, the task is to organize the creation of the TIC to develop a set of measures to overcome the negative trends that exist in the republic [17]. Presented by the authors of the study of the TIC in the KBR, it is focused on solving the problems that are disclosed in table 2 .

Table 2 Goals and objectives of creating a tourist information center

\begin{tabular}{|c|c|}
\hline Goals & Objectives \\
\hline $\begin{array}{l}\text { The formation of an } \\
\text { information } \\
\text { environment to } \\
\text { meet the needs of } \\
\text { all interested parties } \\
\text { (both legal and } \\
\text { physical) }\end{array}$ & $\begin{array}{l}\text { Informing potential tourists } \\
\text { about recreation opportunities } \\
\text { in the region }\end{array}$ \\
\hline $\begin{array}{l}\text { Attracting more } \\
\text { tourists to the } \\
\text { region }\end{array}$ & $\begin{array}{l}\text { Providing tourist information } \\
\text { services for residents and } \\
\text { guests of the republic }\end{array}$ \\
\hline \multirow[t]{4}{*}{$\begin{array}{l}\text { Development of } \\
\text { inbound and } \\
\text { domestic tourism }\end{array}$} & $\begin{array}{l}\text { CBD advancement in the } \\
\text { Russian and international } \\
\text { tourist markets }\end{array}$ \\
\hline & $\begin{array}{l}\text { Improving the quality of tourist } \\
\text { services in the region }\end{array}$ \\
\hline & $\begin{array}{l}\text { Structuring, monitoring and } \\
\text { control } \\
\text { tourist, information, financial } \\
\text { flows }\end{array}$ \\
\hline & $\begin{array}{l}\text { Attracting investment in the } \\
\text { tourism sector of the region }\end{array}$ \\
\hline
\end{tabular}

Therefore, to collect and analyze relevant information on the functioning of resorts, as well as to constantly monitor the situation on the territorial market of tourist and recreational services, it became necessary to create a special structure whose main function would be an organization providing a range of services in the field of tourism and recreation to vacationers [5].

\section{THE DISCUSSION OF THE RESULTS}

The center proposed in the work is aimed at solving the problem of effective positioning of the region as an international tourist resort in the Russian and international markets. At a certain level of development, this center can and should become a unified network organization uniting all participants of the tourism business on the territory. It is assumed that the TIC will have two main components: virtual - in the form of a website and real - in the form of an office (call - center). An important role in the activities of the center will be assigned to telephone service. For this purpose, the center sets the task of creating a call center, which will give answers to phone calls with questions that are related to finding a tourist in the city.

The paper proposes the creation of a logistics center, which differs from the usual TIC in that it uses a logistic approach related to its internal activities, with the construction of interaction with subjects of the tourism industry. The activity of TIC based on logistics management is presented in Figure 1. 


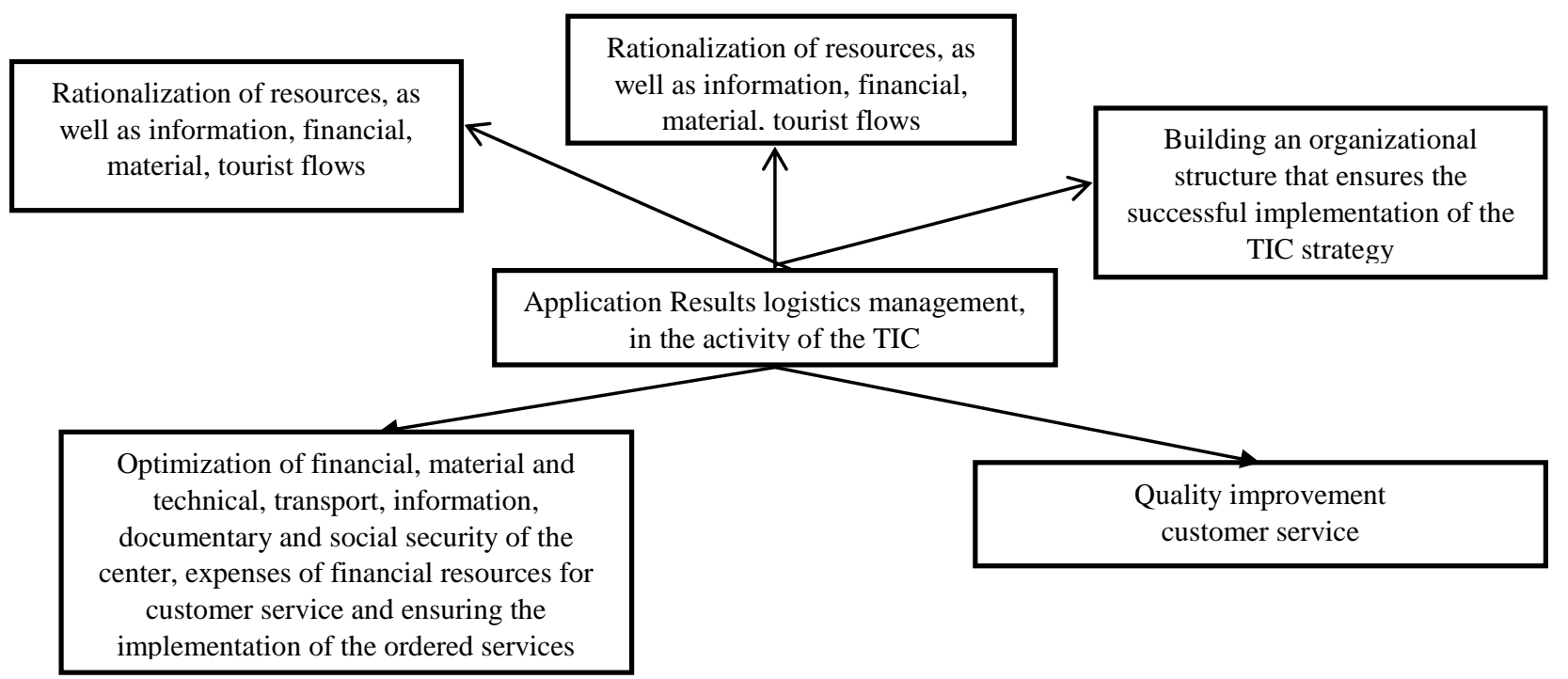

Figure 1 The results of the application of logistics management in the activities of the tourist information center [11].

Logistic TIC is a structure that operates in the markets of information and logistics and consulting services in the field of tourist business processes. The use of logistics management makes it possible for this center to work efficiently, since in this case integrated management of those processes that lead to the formation and provision of services and associated flows is carried out, from the moment when the need for the service arises to the moment when it occurs meeting this need to improve the efficiency of the enterprise. We suggest including the following blocks when creating the center (Figure 2).

For the logistic approach to be implemented at an effective level, it is necessary to single out the subject of logistic management or the corresponding structural unit (unit). It is important to highlight the object of logistic management, which in tourism includes such flows as information, material, financial, tourism, transport and those processes that form and provide services to customers.

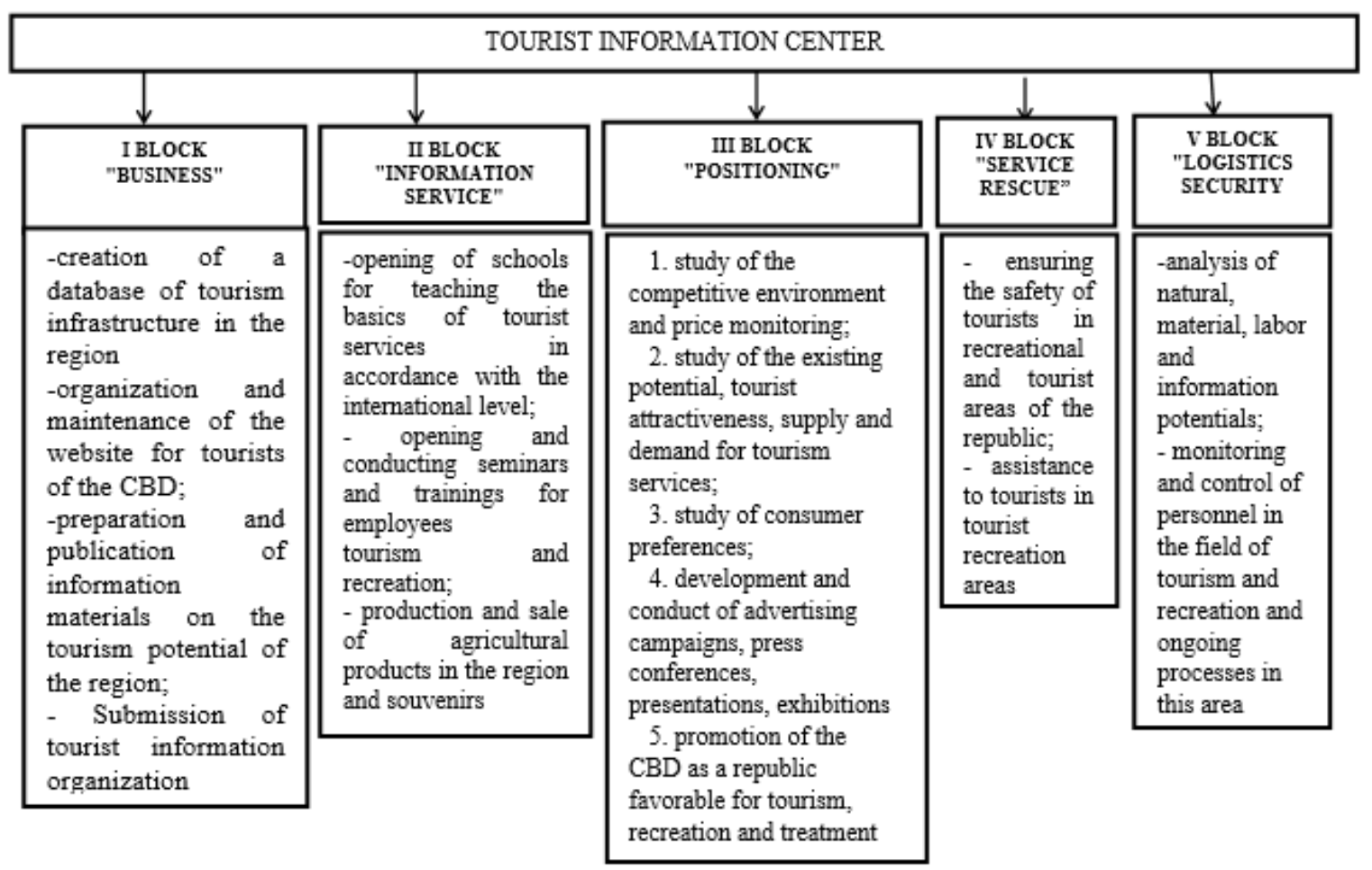

Figure 2 Structure TIC [5] 
It should be highlighted and the subjects of logistics management in the field of tourism and creations. Streaming processes include logisticians, departments and organizations that provide a range of logistics services.

A synergistic effect can be achieved in a tourism organization when it uses a systematic approach to both the subject of management and the object of management. Such an approach to management makes it possible to have a logistical - oriented management subject. Using a systematic approach to managing an object forms a through material flow combining logistics flows and those flows that contain logistics operations. How logistics is provided for the TIC is shown in Figure 3.

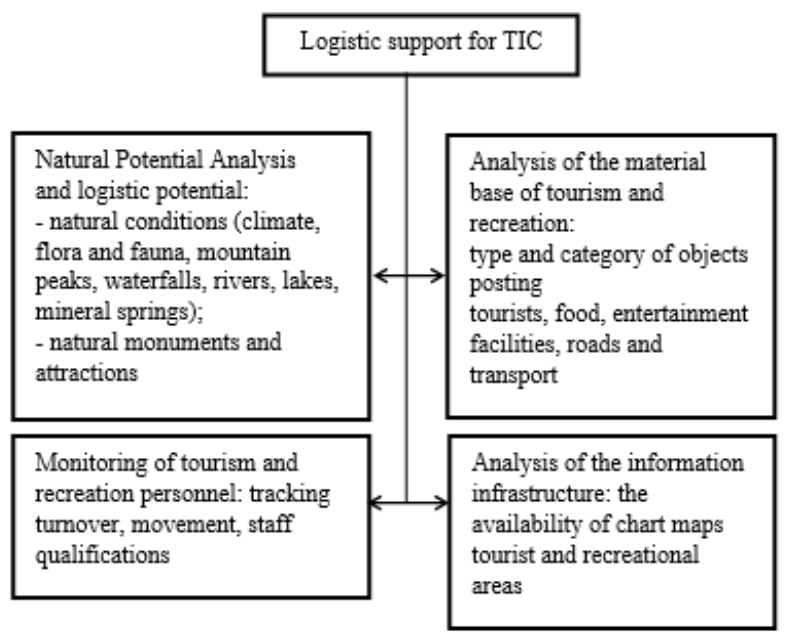

Figure 3 Logistic support for TIC

Tourist information can be represented by tourist navigation, tourist maps, etc. The types of tourist navigation are discussed in detail in Figure 4.

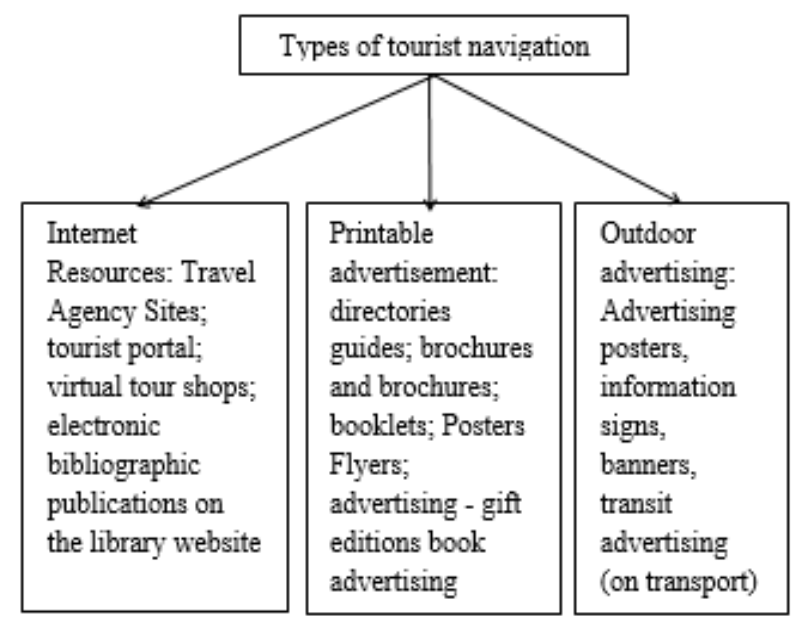

Figure 4 Types of tourist navigation

Tourist map - a geographical map that is intended for tourism purposes. The development of tourist maps requires a special approach. Special requirements are imposed on such characteristics as expressiveness and readability; they should be accompanied by drawings, the presence of photographs, pointers, texts, and various background information.

The tasks of tourist maps include the display of objects of particular interest to tourism. We are talking about architectural and historical monuments, reserves, hotels and other objects, which are depicted on the background of general geographical elements, such as settlements, roads, rivers, etc.). Figure 5 shows the types of maps and cartographic schemes.

We can say with confidence that today there are no competitors who can offer such a range of services in the field of tourism and recreation in the region.

The proposed center, based on logistics management, can be successfully implemented in other regions of the NorthCaucasian Federal District and beyond.

The paper substantiates the necessity and possibility of its implementation in the CBD. Figure 6 shows what the mechanism of the TIC territory is designed to ensure the effectiveness of the tourism sector.

The implementation of various programs and strategic decisions on the development of tourism and recreation will make it possible to significantly increase the influx of foreign and Russian tourists in the region and will allow both inbound and outbound tourism to be developed, setting the optimal ratio between them. It is, of course, also about the creation of a large multidisciplinary tourist and recreational complex in the North Caucasus Federal District.

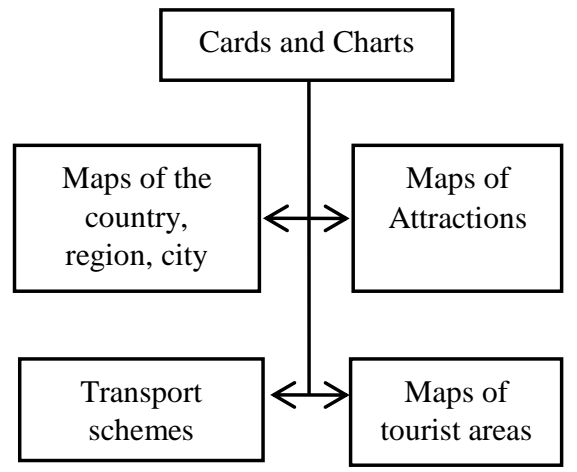

Figure 5 Classification of maps and schematic diagrams

The created TIC will allow the main goal, which is contained in the development strategy of the North Caucasus Federal District, to create a modern highly efficient and competitive tourism sector that will ensure the satisfaction of the diverse needs of the population in tourism services, and secondly, make a significant contribution to socio-economic development region, since the budget will receive additional tax revenues, the influx of foreign currency will increase, the number of jobs will increase, rationality will be maintained but the use of cultural, historical and natural potential. 


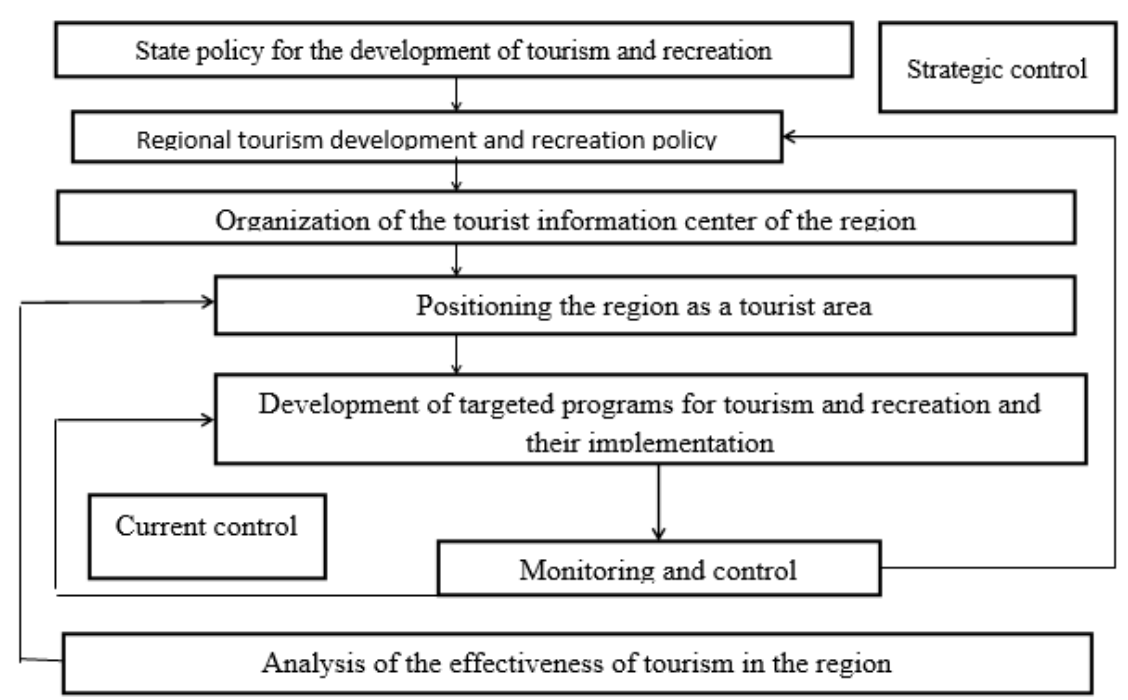

Figure 6 The mechanism of the tourist information center of the territory [12]

So, the availability of rich natural resources and great cultural heritage in the region is far from enough to be considered as the only and sufficient condition for tourism and recreation to develop successfully in the republic, and to promote the region to the world, Russian and domestic markets, given with national and state interests. Considering the high level of costs and the long payback period of investments, taking into account world experience, to solve the tasks set in the work, the most effective and efficient development tool is the use of public-private partnerships.

An equally important task, from our point of view, for the development of tourism in the North Caucasus Federal District, is the development of small and medium-sized businesses. which not only contributes to the development of tourism and increase its contribution to the economy of the territory but also has a significant effect [14]. This was emphasized by the President of the Russian Federation Vladimir Putin in a written letter to the participants of the Vladimir Economic Forum "Entrepreneurship and Tourism: Investing in the Future", which took place in May 2017 [8].

\section{CONCLUSION}

The importance of digital technology for the modern economy is undeniable. Everywhere around the world, in every industry and every company, people digitize what they do. In a truly digital economy, digital technologies penetrate every industry and its fields, from agriculture and pharmaceuticals to tourism and recreation. They are deeply embedded in production processes and are aimed at improving economic indicators [1; 3]. Russia and its regions, using foreign experience, are taking initial, but confident steps for the transition to a digital economy.

One of the most important areas of the Russian economy is tourism and recreation. Studies of this sphere in the North
Caucasus Federal District and in the regions that are part of it have shown that information support for tourism and recreation requires much to be desired. One way to solve this problem is to create a TIC. The tourist and recreational sphere of the Kabardino-Balkarian Republic was taken as the object of study. Her example shows organizational and economic tools for creating a center. The necessity of creating a TIC with the involvement of public-private partnerships and the active development of small and medium-sized businesses in this area is substantiated. According to the same scheme, it is possible to create a center in any other region.

The developed design methodology of the KBR TIC is based on international and domestic experience, and its implementation will allow obtaining significant effects in the development of tourism in the region: accelerate the pace of development of the tourism and recreation sector, educate the population in the spirit of environmental awareness, attract attention and preserve the cultural and historical heritage, popularize republic, to promote information on objects of tourist shows, to attract the population of the territories to the development of new tourist routes, to promote injury to national traditions, to develop the tourism potential of the region to achieve positive dynamics of development of tourist - recreational sphere, increase the budget revenues of all levels to create favorable conditions for solving socio-economic problems in the region.

\section{REFERENCES}

[1] Bogomazova I.V., Anoprieva E.V., Klimova T. B. Digital economy in the tourism and hospitality industry: trends and prospects. Text of a scientific article in the specialty. Service in Russia and Abroad Vol. 85, 2019 
[12] Chadova Z., Tappaskhanova E., Zumakulova Z., Abrhám J. Tourism security and sustainability: a case study of north caucasus region. Journal of security and sustainability issues. 2015. v. 4. No. 3. p. 509-519.

[3] Kapranova L. D. Digital economy in Russia: state and development prospects. URL: https: // cyberleninka.ru/article/v/tsifrovaya-ekonomika-v-rossiisostoyanie-i-perspektivy-razvitiya (accessed: 11.29.2019).

[4] Model Law on Tourism Activities (adopted in St. Petersburg on November 16, 2006 by resolution 27-15 at the 27th plenary meeting of the interparliamentary assembly of the CIS member states). URL: http: // www. lawrussia.ru/bigtexts/law_3212/page3.htm

[5] Thamitlokova Yu.O. Tourist Information Center as a tool for the development of the region's leisure industry, International scientific and practical conference: Science and innovations in modern conditions: at 4 h. Part 1. Ufa, 2017. 229 p.

[6] On the development strategy of the information society in the Russian Federation for 2017-2030: Decree of the President of the Russian Federation of 05.09.2017, No. 203. URL: http: // www.kremlin.ru/acts/bank/41919 (accessed: 11/28/2019).

[7] The list of instructions following the meeting of the Council on Culture and the Arts of October 11, 2012. website. 2013. Access mode: http: //www.kremlin.ru/assignments/16661

[8] Entrepreneurship and tourism: investing in the future. Ladimir Economic Forum - 2017. URL: https://www.vladimir.kp.ru/daily/26680.4/3702384/

[9] The program "Digital Economy of the Russian Federation." URL: http://static.government.ru/media/files/ 9gFM4FHj4PsB79I5v7yLVuPgu4bvR7M0.pdf (accessed: 12.20.2019).

[10] Order of the Government of the Russian Federation of September 20, 2019 N 2129-r <On approval of the Strategy for the development of tourism in the Russian Federation for the period until 2035>

[11] Thamitlokova Yu.O. Management tools for the resource potential system of tourism and recreation Economics and society. Vol. No. 2 (33). 2017. [Electronic resource]. - Access mode: http://www.iupr.ru.
[13] Cherevichko T. V., Temyakova T. V. The Forms of Tourism Digitalization. Izv. Saratov Univ. (N. S.), Ser. Economics. Management. Law, 2019, vol. 19, iss. 1, pp. 59-64

[14] Tappaskhanova E.O., Mustafayeva Z.A., Ligidov R.M., Kudasheva M.Z. Development of innovative business in the industry tourism as the most important factor of employment of youth in north caucasion federal district. International business management. 2015. Vol. 9. No. 7. p. 1668-1678

[15] Tappaskhanova E.O., Mustafaeva Z.A., Tokmakova R.A., Kudasheva M.Z. Development of the tourist-recreational complex of the region. Economy of the region. 2015.No. 2 (42). from. 208-219.

[16] Tatuev A.A., Nagoev A.B., Savchihkina E.P., Loginova O.A., Kiseleva N.N. Guality and innovations as factor of consumer appeal of regional hotel service International Business Management. 2016.V. 10. No. 19. S. $4605-46$

[17] Tatuev A.A., Nagoev A.B., Rokotyanskaya V.V., Kiseleva N.N., Sundukova D.A. Innovative methods of assessment of tourism and recreation sector enterprises: regional aspect, International Business Management. 2016.V. 10. No. 19. S. 4611-4618. 